\section{Historical portraits of the underdog}

\author{
Alan Holland
}

Vivisection in Historical Perspective. Edited by Nicolaas A. Rupke. Croom Helm, London/Methuen, New York: 1987. Pp. 373. £45, \$85.

The Animal Estate: The English and Other Creatures in the Victorian Age. By Harriet Ritvo. Harvard University Press: 1987. Pp. 347. \$25, £14.95.

The Criminal Prosecution and Capital Punishment of Animals: The Lost History of Europe's Animal Trials. By E.P. Evans. Introduction by Nicholas Humphrey. Faber \& Faber: 1987. Pp. 336. Pbk£4.95, \$7.95.

THE use of animals in connection with weapons testing is no new thing, it seems. Paul Elliott places the origins of experimental physiology in nineteenth-century France not in the Paris medical school, as one might expect, but in the veterinary schools of the provinces where horses, those doughty vehicles of war, doubled as experimental subjects. In this and many other ways, what William Paton calls "the erosion of simplistic ideas" is the keynote of Nicolaas Rupke's first-rate collection of essays on the history of vivisection.

The book enhances our understanding of the anti-vivisection movement in two ways. First, it enables international comparisons to be made: the situation in England may be plotted against that in France, Italy, Sweden, the United States, Germany and Switzerland, and we see, for example, the remarkable similarities in the social composition of the humane movement in these countries. It is unfortunate that we have no news of the Netherlands, in the light of Judith Hampson's observation that this country currently enjoys the world's most advanced system of regulation of animal experiments.

The second area of enlightenment concerns the points of contact between vivisection and matters such as the status of science, the sources of political and moral authority and, especially, the cause of women. In a particularly fine contribution, Mary Ann Elston warns against misreading this last connection. There was bound to be overlap, she argues, given that vivisection was the subject of public debate, and that the women's issue concerned precisely the place and role of women in public life. Moreover, women formed the majority in most of the big philanthropic societies, thus enacting their role as 'civilizers'; and in any case, as Elston crisply observes, "disquiet about vivisection was not confined to those who joined societies" (p.267).

Of equal importance, though, are those contributions that focus on the emergence of experimental physiology itself, and provide insight into the aims and methods of such leading figures as Magendie, Bernard, Marshall Hall and J.S.B. Sanderson. Vivisection is seen as integral to the nature and status of physiology and, later in the nineteenth century, of medicine. It was integral, too, as Rupke

observes, to the status of the practitioners themselves, those upwardly mobile scientists who caught, as it were, the fading blasts of aristocratic and religious scorn. In this way, although the nineteenthcentury arguments anticipate those now current, the sources of conflict are surely somewhat different. Moreover, medical benefit seems to have been less of an incentive then than now, only coming to the fore in works such as Richard Owen's Experimental Physiology: Its Benefits to Mankind, published in 1882 . There was also some reluctance to stress such bene- fits in justification of vivisection. This was no doubt due in part to the absence of hard evidence but it seems also to reflect a certain sensitivity. From opposing sides, both Ludimar Hermann and Ernst Grysanowski, who come across as among the more thoughtful contributors to the debate, expressed the view that such justification was both ignoble and egoistic.

An idea long overdue for erosion is that the human exploitation of animals has its roots in Christian teaching, perhaps laced with a touch of Greek influence. The revisionist view propounded by Harriet Ritvo, and substantially borne out by all three books under review, is that an earlier view of animals which conceded to them some independence and power, and which was assailed but not overturned by Descartes, only yielded in the eighteenth and nineteenth centuries to one that justified rampant exploitation.

Ritvo paints a vivid and even exuberant

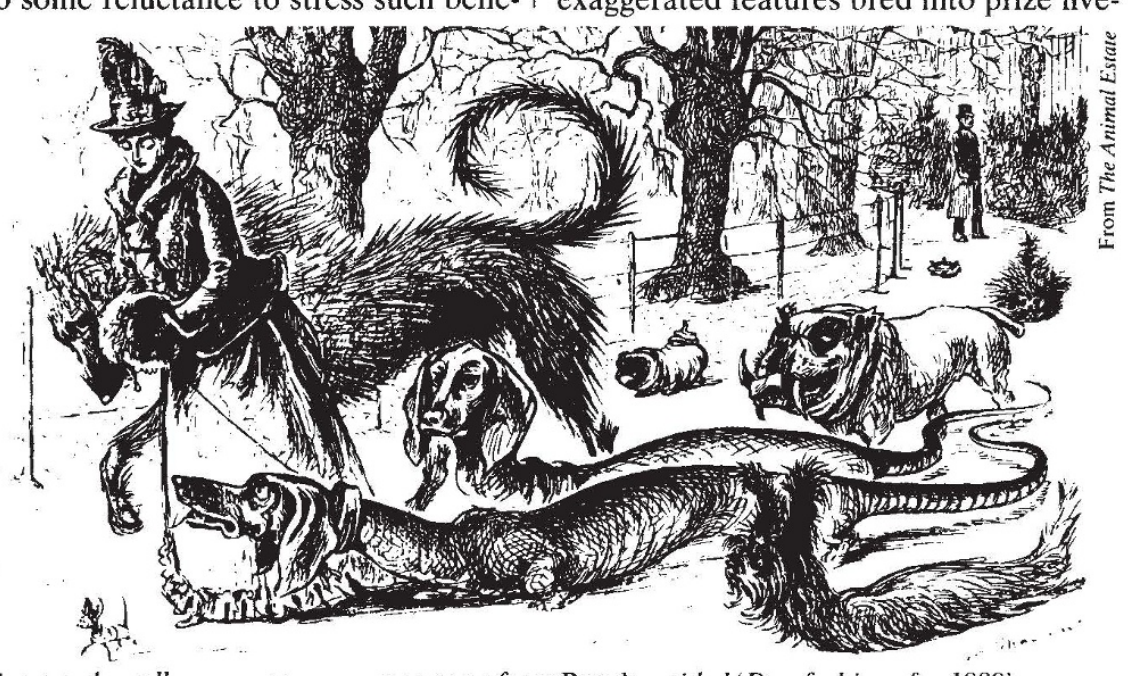

Great and small - a contemporary cartoon from Punch entitled 'Dog fashions for 1889'

picture of such exploitation in full spate. Her portrait of Victorian England is based on the soundest evidence - the writings of those most closely involved with animals, as found, for example, in the records of animal organizations and in the specialist journals. Her theme is the manner in which this 'animal-discourse', and the treatment of animals that it reflected, served other rhetorical functions, not least the celebration of human domination in general and that of certain social groups in particular. Specifically, she shows how popular zoology was slanted to reflect the structures of human society; how livestock and pet breeds served to celebrate the superior status of their owners; how the animal protection societies harboured anxieties about social discipline; and how menageries and game-hunting expressed Britain's imperial aspirations.

This is no mere 'reading' of the material, for her thesis is surely a response to some genuine gaps in our understanding of Victorian attitudes towards animals. Some explanation is called for of the exaggerated features bred into prize livestock, which bore little relation to the needs of practising farmers. Animals could indeed be a danger to public health, but why did the Illustrated London News spy "dissipated canine ne'er do wells" (p.179) lurking at every street corner?

My reservation about the book is that Ritvo occasionally overplays her hand, as when she attaches significance to Darwin's use of "refuse" - just a stylistic variant, surely? - in describing the failure of wild animals to reproduce in captivity, and takes it to signal a view of the animals in question as defiant. It is hardly up to the animals whether they "breed", as opposed to "couple" (a distinction which Darwin carefully observes several times in the passage in question), and if there is a challenge here it is surely to human ingenuity rather than to human authority.

A more important point, perhaps, because it bears on a distinction between ostensible and real significance which 
permeates her discussion, Ritvo does not always make it clear what level of understanding of the real significance of their actions is being attributed to the agents involved. Examples are her reference to "the rhetoric of conquest that [Sir Stamford] Raffles planned to embody in the Regent's Park Zoo" (p.206), and to the desire of Londoners to "view exotic animals in chains and cages" (p.207). Londoners were anxious to view the animals; and the animals were - perforce - caged. It by no means follows that the people concerned desired to view caged animals as such. Overall, there is a hint of caricature in the picture.

What we cannot now see as anything

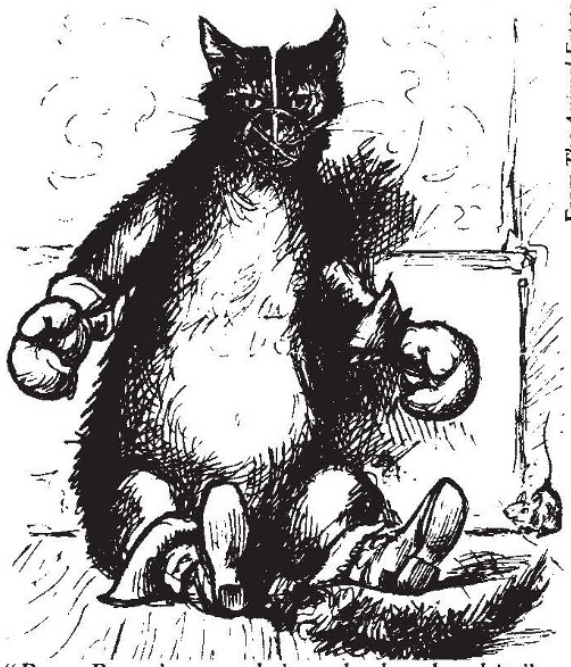

"Poor Pussy's scratch is as bad as her bite" anti-rabies measures inspired this Punch cartoon of 1889.

but caricature are the 190 or so animal trials, which took place throughout Europe and North America between AD 824 and the nineteenth century. In 1906 E.P. Evans rescued records of the trials from oblivion, and we can only be grateful to Nicholas Humphrey for the timely reprint of his book.

The unlikely work of an unlikely manan American professor of modern languages, of Welsh extraction, who lived in Germany and wrote about animals - The Criminal Prosecution and Capital Punishment of Animals has an endless capacity to surprise and challenge the reader. Evans records how assorted domestic animals, rodents, insects and other creatures were variously excommunicated, hanged, burned, strangled or 'knocked on the head' for crimes ranging from crop damage to homicide. What is remarkable is neither the killing of the animals nor the manner of their deaths; rather it is the fact that they were subjected to the full panoply of the law, extending, for example, to the engagement of advocates and the provision of the 'King's bread'.

Even more remarkable, in their way, are the occasional glimpses we get of mercy tempering justice. In Austria in 1519 , moles were guaranteed safe- conduct (from the predations of dogs and cats), and the pregnant females, with their young, were granted an extra 14 days leave, before being obliged to vacate their existing premises; they were, it so happened, considerably inconveniencing the local residents. In a sodomy case at Vanvres in 1750 a she-ass was adjudged to have been raped, and therefore saved from execution, after testimony as to her good character from the priest and other worthies of the town.

Humphrey suggests we see behind these trials the need to make sense of seemingly inexplicable events by redefining them as crimes, thus implying, for example, that "the pig knew very well what she was doing" (p.xxvi). Curiously enough, however, although Evans expostulates over the "irrational and absurd" nature of the trials, he too believes that "animal intelligence is capable of distinguishing between right and wrong" (p.247). In fact he holds that the capital punishment of an insane person (and even of an ox) would be justified if it deterred other insane people (or other oxen). Moreover, it needs to be said that although Humphrey rightly directs us to the fascinating question of the thinking behind these trials (how much we would understand if we could understand that!), what his foreword does not prepare us for is the fact that Evans's review of the trials is but one half of a thesis. The other half is that contemporary treatment of human criminals tended towards excessive commiseration and "maudlin sympathy" (p.203) explicable only as the "violent recoil' from previous practices - and almost equally to be denigrated. Evans was a man who recommended the sterilization of the unfit (p.221), and was someone for whom the electric chair was the last word in modern consideration for the criminal (p.210).

Alan Holland is a Lecturer in the Department of Philosophy, University of Lancaster, Bailrigg, Lancaster LAI $4 Y T, U K$.

\section{Selected passages}

\section{Niles Eldredge}

The Essential Darwin. Edited by Mark Ridley. Unwin Hyman, London: 1987. Pp. 271. £14.95.*

IT MUST be a source of wonder to scientists not daily engaged in evolutionary biology that the words of Charles Darwin continue to have such import in the discipline he founded. We read Darwin because he had it right, or nearly so, about many of the fundamentals of the evolutionary process. In particular, of course, Darwin was able to specify the nature of the dynamic process underlying the design of organisms - namely, "natural selection", the deterministic (if stochastic) governor of stasis and transformation of organismic phenotypes. It is instructive that he did so despite holding erroneous conceptions of the underlying processes of heredity; wisely, Ridley has included these as well as the more enduring ideas in his collection of darwinian excerpts.

Because Darwin knew that organisms vary within local populations of species so that in a world of finite resources some would be bound to fare better than others - and because he saw that offspring tend to resemble their parents, he realized that the features of the more successful members of a generation would tend, on average, to be passed along preferentially to the next generation. The details of how the heredity process actually works are irrelevant to the basic conceptualization of natural selection. Darwin's was a

*In the United States published by W.W. Norton as The Darwin Reader, price \$19.95. genuine discovery. Being the first on the block, so to speak, Darwin devoted his considerable talent and tenacity to rewriting the biology of his day "in the light of evolution", to borrow Dobzhansky's phrase. Much of his explorations of the implications and ramifications of evolution remain important today. Indeed, as one example, Darwin's distinction between natural and sexual selection (not articulated until the Descent of Man, 1871) has only recently begun to receive the attention and acceptance that it has always deserved.

For these reasons alone, Ridley's compilation of passages which, to his generally judicious eye, best spell out the important ideas in nine of Darwin's books, is most welcome. As an undergraduate, I approached the Origin with trepidation. Overawed by Darwin's reputation, and cowed by Victorian English usage, it took a while for the clarity of Darwin's thought and the gentleness of its expression to come through to me. I hope that, in producing this anthology, Ridley will succeed in his quest to bring Darwin closer, especially to students - whetting their appetites and inspiring them to explore Darwin further on their own.

Niles Eldredge is at the American Museum of Natural History, Central Park West at 79th Street, New York, New York 10024, USA.

- For those who prefer the unabridged version, Pickering \& Chatto, London, and New York University Press are in the process of publishing The Works of Charles Darwin in 29 volumes, edited by Paul H. Barrett and R.B. Freeman. Volumes 1-10 are published in 1987, and include a general introduction to Darwin's work, the zoology of the Voyage of HMS Beagle, and two essays on the foundations of the origin of the species. Volumes 11-29 are due out in 1988. 